\title{
Community of Values as a Key Factor of Decolonization
}

\section{Dekolonizasyonun Temel Bir Faktörü Olarak Değerler Topluluğu}

\author{
YAROSLAV PASKO D \\ Borys Grinchenko Kyiv University
}

\author{
GENNADIY KORZHOV \\ National Technical University of Ukraine
}

Received: IO.II.2OI9 | Accepted: IO.OI.2O2O

\begin{abstract}
The article deals with the problems of decolonization in Poland and Ukraine. The relationship between the moral-regulatory and functional foundations of the development of national communities in the process of eliminating colonization heritage is scrutinized. The authors endeavor to analyze the contrast between the two versions of decolonization embodied by the most active forces of social change in the two states: Solidarity and Maidan communities. These social groups act as bearers of certain intellectual and social visions of the future, representing certain historical and value markers. The article generalizes theoretical approaches related to Central European and Russian sociocultural influences relating to the formation of the values of freedom that conflict with the dimensions of clientelism and subjugation. The research confirms that Ukrainian society mostly neglects the heritage of Central European communities: communitarian social experience, solidarity, and social pragmatism. At the institutional and life-world (Lebenswelt) levels the values and principles that were extremely relevant during the events of the $20 \mathrm{I}_{4}$ Revolution of Dignity and led to the overthrow of the Yanukovich colonial regime are currently ignored. On the contrary, Polish Solidarity can be considered a successful anticolonial community which through its powerful intellectual reflection and rethinking of the historical past has been able to offer society a valuable vision of change and to uphold its practical realization
\end{abstract}

Keywords: Decolonization, post-communist transformation, community of values, Solidarity, Maidan.

\footnotetext{
$凶$ Yaroslav Pasko

Borys Grinchenko Kyiv University, Faculty of History and Philosophy, Dep. of Philosophy 04053, Kyiv, Ukraine|paskocivil@yahoo.com

$凶$ Gennadiy Korzhov

National Technical University of Ukraine, Igor Sikorsky Kyiv Polytechnic Institute 03056, Kyiv, Ukraine|korzhovga@gmail.com
} 


\section{Introduction}

To overcome the remnants of the Soviet heritage in post-communist societies is one of the central problems for the modern theory and practice of social transformations. In this context the problem of shaping a new ethos as a symbiosis of social relations and values becomes very relevant. At the same time situation after the velvet revolutions in Central and Eastern Europe was very difficult and the state of affairs in the social sphere was changing very slowly. The value evolution has been blocked due to the absent radical transformation of post-communist societies. The moral-normative corrosion significantly limited the process of complex decolonization, namely: the restoration of sovereign principles of national development and value distancing from Soviet and Russian cultural markers.

The cultural and normative dimensions of decolonization, and the quality of lifeworld (Lebenswelt) are considered in our research as criteria for the separation between Central and Eastern Europe, and a major factor of political autonomy from the Russian-Soviet civilizational heritage. Culture as informality of norms and practices plays a key role in the institutional changes, produces sovereign policy for national communities, and determines a vector of the further development of society (Wagner, 20I4). The research objective is to develop the conceptualization of two 'ideal types', in Max Weber's terms, two patterns of postcolonial transformations, which are products of various social and cultural experiences (Weber, 1998: 104-156). The processes of decolonization in Ukraine and Poland are based on fundamental differences in identities and shape different 'windows of opportunity' for each of these countries.

The first pattern is related to the hegemony of the imperial inheritance, continuing cultural and civilization dependence on the former metropole, and the lack of reflections regarding national future. Ukrainian historical memory (except Galicia) has not been seriously influenced by Austro-Hungarian and Central European cultural markers and is highly dependent on experience shared with Russia. Russian historical symbols, built on the idea of the eternal unity of the 'brotherly nations', of the 'common victory of I8r2' and of the 'great victory of I945', continue to be significant to millions of Ukrainians. An important ideological instru- 
ment of imperial influence is the concept of 'Russian world', which is largely a socio-cultural mixture: the moral and normative foundations of the Russian Orthodox Church, the philosophy of Eurasianism, and the politics of neo-imperialism. It envisages the dominance of the Russian language and Russian organization of public life as a common marker for the entire Orthodox ecumene. This project is deeply rooted in the Ukrainian mentality (especially of Eastern Ukrainians) and appeals to a common historical mission of Ukrainians, Belarusians, and Russians as the common people able to preserve their original traditional virtues and to resist external aggression. At the same time, there is an ideologically imposed distrust of the Poles as part of the Catholic European world, who at religious, cultural, social, and political levels are presented as unacceptable and even hostile to Ukrainians. The Russian socio-cultural paradigm in Ukraine is reinforced by the historical recollections of Ukrainians about 'bloody events in East Galicia and Volyn', that did not in any way help to bring Ukrainians closer to the Poles as an embodiment of European cultural foundations and value heritage. In conditions of cultural and socio-economic uncertainty, in the absence of a coherent cultural policy of the state to preserve national memory, Ukrainians face difficulty in overcoming their dependency on Russia, which by using powerful media resources and social networks continues to substantially affect social behavior of Ukrainians, and to exacerbate controversy within different Ukrainian communities. In this context, 'Ukrainian dualism' is considered as an inability to overcome the historical controversies and cultural dependence on the colonizing power (Zabuzhko, I997: 42).

The second strategy is based on strong traditional identity and rethinking of the occupation period. The concept of the organic combination of national community, culture, and politics acts as a decisive factor in the Polish model of decolonization, first and foremost, in terms of overcoming the colonial heritage. This synthesis enabled the formation of the Third Republic and transformed the formerly atomized society into a value-based community that consistently displaces colonial stereotypes and rudiments of Soviet historical memory from its own use. At the same time, the culture and policy of the empire are not simply rejected, as in case of the first pattern, but become the object of analysis, an integral 
part of historical memory and intellectual reflection.

The hypothesis of the research posits that the Ukrainian version of decolonization is extremely problematic for the further modernization of values in the country. The current model of imperial dependence produces a powerful influence of the colonial socio-cultural narrative on the Ukrainian community. The consequence of this process is the facade rather than the real de-communization and the lack of comprehensive intellectual reflection on the imperial heritage, the absence of a meaningful cultural, socio-economic and political program of social change, a strategy of providing values separated from the imperial ones. In the article we will try to understand the ability of the leading communities of decolonization, Solidarity and Maidan, to become the driving force of decolonization and to ensure the successful transformation of Poland and Ukraine respectively.

\section{Methodological Foundations of Research}

The model of imperial hegemony is well-grounded in the collective exploration of Bill Ashcroft, Gareth Griffiths and Hellen Tiffin's (2002) The Empire Writes Back: Theory and Practice in Post-Colonial Literatures. They identify the theoretical foundations of colonial discourse, and the relationship between colonizers and the colonized in the European concepts of structuralism, post-structuralism, and Marxist criticism (Ibidem.: 30). In this context it is important to mention works by Gayatri Chakravorty Spivak (I988) and Homi Bhabha (2004) that laid the foundations of contemporary post-colonialist studies.

One of the founders of post-colonial theory, Edward Said (Said, 2007) gives confirmation of the applicability of post-colonial theory to post-socialist societies, such as Polish and Ukrainian. He points out that Orientalism, although based on a cultural distinction between the European and Asian parts of the world, was not uniquely related to the true East, but rather to a certain categorical field that defines this word (2007: 27). Timothy Snyder (2015) has a similar position and re-conceptualizes the Soviet-Russian 'social project as colonial' in the context of Russia's aggression against Ukraine.

The consistent opponent of the idea of external colonization is Alexander Etkind (2OII), a Russian scholar who emphasizes the distinction 
of the Russian empire from European empires. He argues that the latter provided economic and political benefits to their colonies, creating opportunities for self-government and self-sufficiency. The author of the work Internal Colonization: the Imperial Experience of Russia considers the Ukrainian community as an example of 'non-classical colonization, when the ethnically homogeneous population is incorporated into the empire, forming the cultural and political differences of the other as their own.' (Etkind, 20II: 229)

Andreas Kapeller (2OOI) states that 'all Ukrainians ... gradually become a regional type of Russians and completely fall out of the ethnic hierarchy' (24). The researcher focuses on the co-optation of the Ukrainian elite to the imperial form of social organization, the loss of subjectivity, which, despite all the years of Ukrainian independence, blocks the processes of national self-determination. As a consequence, Russian culture, even in its simplistic forms, is perceived as a universal and indisputable pattern of imitation.

To this stream of post-colonial studies we can also attribute Mykola Riabchuk (2015), Tamara Hundorova (2007), and Oksana Zabuzhko (1997). Mykola Riabchuk (2015) actualizes the analysis of Russian imperial practices and their impact on the formation of Ukrainian identity. He used postcolonial metaphor 'creole state' for describing post-communist Ukraine and suggested considering Ukrainization as Westernization and decolonization at the same time. In the context of comparative analysis between Polish and Ukraine perspectives, Riabchuk pointed out that in Ukraine the postcolonial situation was defined in terms of dependence and subservience, while in Poland historical experience could be linked both to the perspective of the colonized subaltern and to that of the colonizer with regard to the multiethnic eastern territories (2015: 76).

In this respect, the Polish anti-occupation discourse looks more rigorous and convincing, embracing various figures from Jerzy Giedroyc to Czesław Miłosz, from Witold Gombrowicz to Jan Sowa.

The importance of post-colonial theory for the Polish experience of post-communist transformations is confirmed by Ewa Thompson (2000). The researcher applied the postcolonial perspective arguing that 'though classical colonies are territories whose conquest requires overseas travel, 
which was not the case of Russia, the process of territorial expansion was also form of colonization'. She emphasizes four constituents of the postcolonial situation characteristic of Poland as follows: I) poverty that hinders the development of strong institutions and autonomous culture; 2) 'African pessimism' viewed as post-communist negativity and lack of positive expectations for national development and trust within one's own society; 3) unjustified belief in one's own national greatness, and, finally; 4) culturalism as reducing all the problems to the inappropriateness of one's own culture, its lower status, the blaming of the victims of colonization, who have been unable to get rid of bad habits, to change in the right direction, and to be re-educated (Thompson, 20IO; Thompson, 2000). Other authors are more skeptical of the applicability of postcolonial theory to the analysis of Polish experience. In particular, Snochowska-Gonzalez (2OI2) argues that the use of post-colonial theory in Poland is part of the process of simplifying history by the right-wing political forces to be used in anti-Oriental rhetoric against Russia.

In the context of these theoretical approaches, we consider that Ukrainian and Polish socio-cultural transformations are well within the context of postcolonial studies. Examined from this theoretical angle, the long-term experience of the 'blocked' cultural and political life, in Lina Kostenko's terms, has led to significant problems with the national selfdetermination of Ukrainian community, its ability to choose a sociopolitical paradigm for further development, and to make a choice between two existing historical options: Central Europe and Russia.

\section{Solidarity and Maidan: 'Anti-Colonial Communities' or Value Challenge to Metropole?}

From the time of antiquity, it is well-known that the moral and normative community is a source of solidarity formation, an important condition for the legitimization of cultural and civic experience. The functioning of the community is based on the pre-modern values that are decisive in the process of forming resistance to Soviet and Russian colonialism in Central and Eastern Europe. Yevhen Sverstyuk (2014) rejected the geopolitical approach depicting Ukraine as a buffer zone between Europe and Russia in favor of a fast community transformation to 'European moral-normative values'. 
Moral and normative principles are inseparable from limiting pragmatic yearnings in the community from overcoming the rudiments of the colonial past. Barbara Szacka emphasizes that it was the moral and normative dimensions of the Polish community that did not allow them to accept the Soviet version of historical memory, the heroes whom they imposed in the framework of this historical version (2006: 54).

The significance of value judgment in the lives of the subjugated peoples was repeatedly accentuated by John Paul II (1996) who during his trips to Europe in the $1970-80$ s showed an example of convincing critique of both communist power and liberal principles and offered as an alternative its own integrative vision of social changes related to community reinvigorating values. The importance of values can hardly be overestimated because 'a community without values can easily become an instrument of totalitarianism' (John Paul II, I996).

Andrew Mason (2000), a theorist and historian of communities, advocates a similar position. In addition to the usual criteria of community such as shared values, lifestyle, identification with the group and its practices, and mutual recognition, he introduces the concept of the 'moral dimension of community' (II 7 ). The above approaches adequately capture the role of pre-modern foundations in the formation of Polish identity. Traditional values serve as a social and cultural marker of the community, a prerequisite not only for the processes of decolonization, but also for further modernization of the Third Republic. David Ost (2014), one of the most famous theoreticians of the Polish transformation, states that revolutionary changes have become part of a radically different view of the world which does not provide for the decisive role of the communist state but depends directly on the unifying efforts of communities and groups, their evolution on a non-political value levels (II 7 ).

Polish experience of decolonization is inseparable from the actions of the national community which proved to be able to break with the colonial past and to propose a post-occupational vision of its own future. This vision became an important factor in further modernizing the country at the turn of the communist era as well as socio-cultural demarcation of Poland from the Soviet heritage. Having received general support from Polish intellectuals and the church, Solidarity created the prerequisites 
for the further overcoming of Soviet colonialism which became visible after the overthrow of the communist regime.

We can observe the significant differences in the historical valuation of the past within strategies of two nations - Poland and Ukraine. Ukraine's post-colonial strategy is poorly designed. The inertia of preMaidan vision, where national Ukrainian historical memory disintegrates in the memory of different territories and acts as a form of manipulation of regional elites, remains strong enough. A relevant example is the position of the leader of Kharkiv region, G.Kernes, who in every way restricts the presence of Ukrainian symbols in Kharkiv, and simultaneously attributes a greater importance to Soviet and Russian symbols (G. Zhukov, M.Bernes, L.Utesov, I.Konev). As a matter of fact, this strategy results in the prolongation and intensification of colonial discourse in the country. This is clearly visible not only on a daily basis, in the sphere of media, and mental stereotypes of people, but also in the field of education and culture, activities of intellectuals and artists of Eastern Ukraine. On the other hand, intellectuals such as Yuriy Andrukhovich and Anatoliy Karas' underline the peculiarity of Galician tradition as an antidote to the postSoviet cultural space of Eastern Ukraine. We can speak about the vision of Galician identity as part of the Habsburg heritage, revival of national culture, and incorporation of Ukrainians into a broader Central European framework. Mykola Riabchuk pointed out that the 'Western Ukrainians have never internalized communism, never perceived the Soviet Union as their own country, and never believed that the Soviet Army had come to liberate them as it claimed'. He promoted mass consciousness the idea of two Ukraines: whereas in Galicia the 'culture of Central Europe was perceived in one way or another, the East saw the 'brave new world of victorious revolution and proletarian internationalism' (Riabchuk, 2002). In contrast, social researcher Tetiana Zhurzhenko criticized the idea of two Ukraine as a metaphor that might lead to the dangerous demarcation inside the country and thus eventually weaken Ukrainian state (Zhurzhenko, 2005: II4).

Instead of public discussion about the future of our country within the whole Ukrainian society, there is a declarative orientation of the Ukrainian authorities and public organizations on the Western govern- 
ance model and Western values, which does not in any way agree with the existing inefficient system of cronyism and corruption. Client relations dominate at all levels of Ukrainian society. At the embryonic level, a critical reflection on the past remains so necessary for a healthy society. There is no real decolonization without which it is impossible to imagine significant economic and social shifts. Instead, full-fledged decolonization takes place only in the chaotic struggle of the Ukrainian authorities (primarily installed by former President Poroshenko) with monuments of the Soviet past. Quite complex and contradictory processes take place in other spheres of culture, which do not receive from the post-colonial state clear positive impulses regarding their own future. This is not surprising, because it lacks a coherent national strategy for Ukraine, formed by the old post-Soviet political class, linked in value to the imperial past. And this is a significant problem for Ukraine, which continues to remain on the margins of civilizational development due to the irresponsibility of the political elite.

A fundamentally different strategy can be traced in Poland, where, as a result of the general delegitimization of communist social order and the unification of efforts by the broadest sections of civil society, occupational social model was eventually destroyed. Transformation of the country in accordance with European model has taken place. The authentic identity of the Polish community has been re-established in terms of the restoration of moral and normative foundations of social life and the appeal to European authentic functional dimensions of the existence of national institutions. The essay by Milan Kundera The tragedy of Central Europe, saying that the Central European identity was betrayed by the West and placed in the zone of influence of 'Soviet communism', was a prologue for understanding Central European cultural identity by Polish intellectual circles.

In the I980s the intellectual circles of Solidarity viewed the idea of Central Europe as a return to a Europe of values, as a factor in the delegitimization of pro-Soviet regime, and in resisting the occupying communist discourse. They used the Central European heritage as an additional enhancement of their own nation's experience, as well as an attempt to recreate authentic European culture as opposed to cynical 
policies, negative forms of industrialization and technocratic civilization, which were objectively a factor in the marginalization of national culture. In this context Bronisław Geremek pointed out that 'the dream of the central European entity and the natural place of our community are among the values of Europe and Western Christianity. It is the fundamental idea or one of the basic myths of our progress' (Geremek, I994: 239) $)^{\mathrm{I}}$.

The Polish anti-occupational discourse of 'Solidarity' actualizes the academic intellectual reflection related to the cultural and historical contexts of both National and Central European memory, offers the joining of European cultural strategy with the political overcoming its occupation past. Such a model represents discursive and value confrontation between metropole and periphery. National community is considered not only as a subject of its cultural heritage but also as a temporal and political marker of decolonization, as an actor of reflexive decolonization and de-legitimization of the occupation experience.

As the 'Solidarity' experience shows, communitarian principles of social life and a network of informal norms and practices in communities play a decisive role in institutional changes. It is a factor of overcoming the inertia of the past and an inevitable condition for post-occupation development.

Considering the leading role of the Polish national community in the process of overthrowing the communist regime, Dariusz Dobrzański notes that the desire of citizens to form a political community in Poland was '... extremely important and connected with a strong national selforganization that brought it closer to its ideal dimension' (Dobrzański, 2OI3: IO4). Self-organization in the community was best demonstrated not only during the first period of Solidarity but also during the Round Table of i989. In the latter case, despite different attitudes toward the communist authorities, all the participants in order to preserve the unity of Poland reached an agreement to conduct democratic elections and to gradually transfer power.

\footnotetext{
I Having fulfilled its mission, the idea of Central Europe in Poland gave way to the idea of European unity, which was more in line with the pragmatic aspirations of the Poles to join the EU and Euro-Atlantic structures.
} 
Another important factor in the functioning of civil community was its capacity for self-restraint. Characterizing the importance of selfrestraint in Polish 'Solidarity', Alain Touraine points out that for both historians and participants of the revolutionary movement, the most important test was the 'ability to control one's own affairs' and reconcile them with existing reality (Touraine, 2013: I8). First of all, there are three basic components of self-restraint that have been implemented in public life by the leading civil society community in Poland. They are: I) recognizing the party's leadership, 2) Poland's membership of the Warsaw Pact, and 3) agreeing to work with the communist government to resolve the economic crisis. The French researcher notes that for a long time Solidarity has positioned itself as an anti-revolutionary movement, remaining a sufficiently well-organized social force capable of mobilizing the masses of the population on the national scale. While assessing the contribution of Solidarity to the social life of the r980s and I990s, the author of the book Solidarity: The Analysis of a Social Movement: Poland I980-I98I states that Solidarity fits into the list of the twentieth-century freedom communities that have legitimized the idea of progress, and improvement of working and living conditions (Ibidem.: 24).

It is worth noting here the position of one of the most famous commentators of the Central European resistance movements - Andrew Arato, who states that the idea of 'self-restraint of the Polish revolution was a key concept not only for the Polish but also other opposition to the communist authorities of Central European countries (Arato, I984: 13). Solidarity as a leading community of civil society was, according to the researcher, a form of protection for all democratic initiatives and forms of political life independent of the state. Its initiatives can be seen not only in the context of creating an autonomous network of free relationships, but also as a call for an alternative form of public life. For Jacek Kuroń, Adam Michnik and other leaders of civil society, the distance Solidarity kept from the institutions of colonial power was a principal issue, since this power was perceived by the national community as unacceptable and incompatible with the necessary changes for society.

The symbol of value-based delegitimization of Soviet colonialism in Ukraine was the Maidan which without relying on the principles of tradi- 
tional identity united various network communities in Ukraine. In contrast to 'Solidarity', which was deeply rooted in historical and cultural past, the Ukrainian community was largely confined to the combination of well-used media technologies with romantic and emotional impulses of people who opposed the anti-human system from the point of view of protecting their civic dignity.

Unlike Polish society where intellectuals played a key role, in Ukraine they did not become the driving force behind social change, and traditional values have not played a serious role in the unification of society. Maidan became a symbol of the temporary return of dignity by the oppressed, a factor in the grassroots horizontal civil mobilization of people with a strong civic position, people representing various cultural traditions. It became the place for the return of people's faith in the common human values of goodness. That was the symbol of the victory of people who set the ideals over material wealth. However, the Ukrainian 'Agora' has not become a place for the dissemination of sustainable values of the community, which would become the basis for a clearly defined vision of the future. Confronted with the existing colonial markers of the past, the Maidan could not win. Tamara Hundorova (2007: 79) in this context emphasizes that Verka Serduchka, who can be considered as a certain image-totem of post-colonial Ukraine's inferiority,... demonstrates the relativity of the situation of marginality: it can turn into a mainstream, just as the conductor becomes a cult face, she also has a nostalgic flavor.'

The values of the Maidan have not been able to overcome the criminal consciousness cultivated in the captive country for years. In the Polish tradition this type of consciousness is associated with the communist past, it is based on distorted patron-client relations and on the subjugation of the community 'deprived of the right to make decisions' (Riabchuk, 2015: 66). Such a society produces the situation of 'postcolonial syndrome', i.e. the cultural and psychological dependence of Ukrainian society on the Soviet legacy, unproductive ideological orientation towards archaic and compromised forms of social order - products of an alternative historical vision (Ibid.).

The logical consequence of this form of subordination is the orientation of society to simple and verified forms of social organization that are 
characteristic for caste society with the corresponding exclusion of certain groups from the political and social spheres. In practical terms, this means that the ruling class is oriented to Russian models of social governance and blocks changes at the civil grassroots level (Hnatiuk, 2005: 89). At the same time, the existing values of survival of the ruling class and social groups do not contribute to the process of national development.

The peripheral model of exclusion which increases the social servility of society remains the dominant one in today's Ukraine. It fundamentally contrasts with the Central European model of decolonization. The profound weakness of Ukrainian community lies not only in the fact that the experience of Central European communities, which is important for the process of decolonization, is devalued and even completely ignored, but also in the impossibility to achieve modernization, which is extremely important for a morally weak and technologically backward society.

In Ukraine we encounter a reduced version of decolonization, notably: the prevalence of political rhetoric over rational actions. The symbolic violence over the patterns of colonial memory - in the form of demolition of monuments - highlights the lack of a well-thought-out strategy for cultural and political change. In the long run a discourse that focuses on 'alien', 'the other', and the policy of exclusion diverts attention from important internal problems. Social aggression against Russian cultural and political segment as 'other' performs the functions of compensation for humiliation and dependence from the metropole.

It is evident that such a way of overcoming the past provokes the incompatibility between political declarations and practical actions of the political class, especially in the context of recent events after 2014. Ukrainian society has not used those chances for social changes that have emerged. 'A social design of the future legitimized by power and civil society cannot be substituted by lip-service declarations on the European choice of Ukraine' (Pasko, 20I6: 8). It is evident that this scenario is a logical consequence of the long experience of 'inferiority complex' and Ukrainian cultural orientation in favor of more 'prestigious' Russian language, literature, and culture, a social order inherited from Russia. The colonial politics of Russia (Moscow kingdom) led to marked changes in the tradition of Ukrainian toponymy and anthroponymy (Khrypko and 
Iatsenko, 2019). This made impossible the formation of national identity and the creation of value-oriented national community.

\section{Conclusion}

The comparative analysis of decolonization processes in two postcommunist countries exhibits sharp contrasts. In Ukraine they are fragmentary and inconsistent. The main problem is the inability of Ukrainian community, the most active force of which was Maidan, to crystallize Ukrainian society in value terms, to consistently choose and realize the path of social development, autonomous from the Russian one, as well as to strengthen the institutions of civil society. Ukrainian society has not gone through an all-embracing path of decolonization, which involves not only overcoming the inferiority and humiliation complex, rethinking the imperial cultural and political heritage, but also acquiring a certain comprehensive vision of Ukraine's future. The latter is possible in the context of the combination of cultural and academic constituents with a welldefined pro-Ukrainian political standpoint of various communities and groups, which should be supported by the state. In today's context, postMaidan power is not able to ensure a civilized division of business and power. Remaining strongly culturally and civilizationally linked to Russia's imperial heritage, the Ukrainian ruling elite at pragmatic level and largely as a result of deep socio-economic crisis has been forced to choose a way of closer cooperation with the Western world in recent years. But the importance of the Euro-Atlantic vector for Ukraine cannot be exaggerated, as the attempts of change run into fierce resistance from different Ukraine's communities that focus on the inefficiency of 'pro-Western reforms' and the danger of incorporating the 'external governance' model. It is obvious that in the coming years Ukraine will remain a buffer zone between the Western world and Russia, with the simultaneous conflictridden coexistence of pro-Russian and pro-Western communities.

On the contrary, the decolonization path of Polish society can undoubtedly be regarded as quite successful. Owing to the very active forces of social integration of Polish society, first of all, intellectuals and the church, example powerful communitarian values were formed and strengthened, which became an important socio-cultural precondition for national unity and development. Reforms initiated by Solidarity proved 
to be very successful. Their importance for the conservative modernization of $2014-2020$ is hard to downplay. Polish society develops at a rather rapid pace. Poland remains an important example of social success for Ukraine. The Polish model of decolonization based on 'value self-restraint' is an important guide to modern Ukraine.

\section{References}

Arato, A. (1984). The Democratic Theory of the Polish Opposition: Normative Intentions and Strategic Ambiguities. Working Paper 15, April, Kellog Institute.

Ashcroft, B. \& Griffiths, G. \& Tiffin, H. (2002). The Empire Writes Back: Theory and Practice in Post-Colonial Literatures. London \& New York: Routledge.

Bhabha, H. (2004). The Location of Culture. Abingdon: Routledge.

Bottici, C. (2014). Imaginal Politics: Images beyond Imagination and the Imaginary. Washington: Columbia University Press.

Dobrzański, D. (2013). Zasada Solidarności: Studium z Filozofii Społecznej. Poznan: Wyd. Naukowe UAM.

Dzielski, M. (1995). Polityka Polska Dziś. Odrodzenie Ducha-Budowa Wolności: Pisma Zebrane. Kraków: Krakowskie Towarzystwo Przemysłowe, Znak, 919943 .

Dzyuba, I. (1998). Internationalism or Russification? Kyiv: Kyiv-Mohyla Academy.

Etkind, A. (20II). Internal Colonization: The Imperial Experience of Russia. Moscow: Literaturnoye Obozreniye.

Geremek, Bronisław. (I994). Spoleczeństwo Obywatelskie i Wspólczesność. Europa i Spoteczeństwo Obywatelskie. Kraków: Znak.

Hnatiuk, O. (2005). Farewell to Empire: Ukrainian Discussions on Identity. Kyiv: Osnovy.

Hrytsak, Y. (2015). The Postcolonial is Not Enough. Slavic Review, 4, 733-734.

Hundorova, T. (2007). Postcolonial Ressentiment: the Ukrainian Case. From Sovietology to Postcoloniality: Poland and Ukraine from a Postcolonial Perspective. (Ed. J. Korek). Huddinge: Södertörns Högskola, IO3-Iı3.

John Paul II (1996). The Social Teaching of the Church as the Integral Part of its Mission. Rome: Fundacia Jana Pavla II, Osrodec Documentacji Pontificatu. 


\section{https://pbn.nauka.gov.pl/ sedno-webapp/persons/1552204/?\& page $\mathrm{No}=2$.}

Kappeler, A. (200I). The Russian Empire: A Multiethnic History. London: Routledge.

Khrypko, S. \& Iatsenko, G. (2019). Philosophy of a Surname: Ukrainian Context. Beytulhikme An International fournal of Philosophy, 9 (4), 899-912.

Król, M. (I99I). Święty Piotr i John Stuart Mill: Nowożytny Spór Między Ścijaństwem a Liberalizmem. Res Publica, 46 (9-10), 2-23.

Król, M. (1992). Liberalizm Strachu czy Liberalizm Odwagi. Kraków, Znak.

Król, M. (1993). Między Korporacją a Społeczeństwem Obywatelskim. Obywatel: Odrodzenie Pojęcia. (Ed. B. Markiewicz). Warszawa: Instytut Filozofii i Socjologii PAN.

Lis, R. (2007). Fenomen Narodzin Spoleczeństwa Obywatelskiego w Polsce Okresu Schyłkowego Kommunizmu. Czas Społeczeństwa Obywatelskiego. Między Teoriq a Praktykq. (Ed. P. Borowiec \& B. Krauz-Mozer). Kraków: Wydawnictwo Uniwersytetu Jagiellońskiego, 89-IO2.

Mason, A. (2000). Community, Solidarity and Belonging. Levels of Community and their Normative Significance. Cambridge: Cambridge University Press.

Michnik, A. (I983). List z Mokotova: Grudniowe Rekolekcje. Krytyka, I6, II-22.

Novak, M. (1993). Liberalizm-Sprzymierzeniec czy Wróg Kościola: Nauczanie Społeczne Kościoła a Instytucje Liberalne. Poznań: Wydawnictwo W Drodze.

Ost, D. (1991). Solidarity and the Politics of Anti-Politics: Opposition and Reform in Poland since 1968. Philadelphia: Temple University Press.

Pasko, Y. (20I6). Introduction. Z. Krasnodębski. Demokracja Peryferij. (Trans. Y. Pasko \& H. Korzhov \& O. Beliakova). Kyiv: Talkom, 6-9.

Pavlyshyn, M. (1992). Post-Colonial Features in Contemporary Ukrainian Culture. Australian Slavonic and East European Studies, 6 (2), 4I-55.

Riabchuk, M. (2002). Ukraine: One State, Two Countries with comments. Transit Online, 23.

Riabczuk, M. (2015). Ukraina: Syndrom Postkolonialny. Wroclaw-Wojnowice.

Said, E. (2007). Culture and Imperialism. Kyiv: Krytyka.

Shore, M. (2018). Ukrainian Night: History of Revolution Closely. Kyiv: Dukh i Litera.

Snochowska-Gonzalez, C. (2012). Post-Colonial Poland: On an Unavoidable Misuse. East European Politics and Societies, 26 (4), 708-723. 
Snyder, T. (2015). Integration and Disintegration: Europe, Ukraine and the World. Slavic Review, 74 (4), 695-707.

Sowa, J. (2011). Fantomowe Ciało Króla: Peryferyjne Zmagania z Nowoczesnq Formq. Kraków: Universitas.

Spivak, G. C. (1988). Can the Subaltern Speak? Basingstoke: Macmillan.

Sverstyuk, Y. (20I4). Changing Winds of Time. Maidan: (R)evolution of Spirit. (Ed. A. Mukhars'ky). Kyiv: Nash Format, II8-I29.

Szacka, B. (2006). Czas Przeszły: Pamięc-Mit. Warszawa: Scholar.

Thompson, E. (2000). Imperial Knowledge: Russian Literature and Colonialism. Westport \& London: Greenwood Press.

Thompson, E. (2010). Whose Discourse? Telling the Story in Post-Communist Poland. The Other Shore, I (I), I-15.

Tichner, J. (2000). Etyka Solidarności. Kraków: Znak.

Touraine, A. (2013). Solidarnośc: Analiza Ruchu Społecznego 1980-198I. Gdansk: Europejskie Centrum Solidarności.

Wagner, P. (20I4). Does Europe Have a Cultural Identity? The Cultural Values of Europe. (Eds. H. Joas \& K. Wiegandt). Kyiv: Dukh i Litera, 525-543.

Weber, M. (1998). On Some Categories of the Sociology of Understanding. Sociology: General Historical Analysis. Kyiv: Osnovy, IO4-156.

Zabuzhko, O. (1997). Shevchenko's Myth of Ukraine: An Attempt at Philosophical Analysis. Kyiv: Abris.

Zhurzhenko, T. (2005). Myth on Two Ukraines. Perekriestki, 3-4.

Öz: The article deals with the problems of decolonization in Poland and Ukraine. The relationship between the moral-regulatory and functional foundations of the development of national communities in the process of eliminating colonization heritage is scrutinized. The authors endeavor to analyze the contrast between the two versions of decolonization embodied by the most active forces of social change in the two states: Solidarity and Maidan communities. These social groups act as bearers of certain intellectual and social visions of the future, representing certain historical and value markers. The article generalizes theoretical approaches related to Central European and Russian socio-cultural 
influences relating to the formation of the values of freedom that conflict with the dimensions of clientelism and subjugation. The research confirms that Ukrainian society mostly neglects the heritage of Central European communities: communitarian social experience, solidarity, and social pragmatism. At the institutional and life-world (Lebenswelt) levels the values and principles that were extremely relevant during the events of the 2014 Revolution of Dignity and led to the overthrow of the Yanukovich colonial regime are currently ignored. On the contrary, Polish Solidarity can be considered a successful anti-colonial community which through its powerful intellectual reflection and rethinking of the historical past has been able to offer society a valuable vision of change and to uphold its practical realization.

Anahtar Kelimeler: Sömürgecilik, komünizm sonrası dönüșüm, değerler topluluğu, dayanıșma, Maidan. 